\title{
Strategies Used by Teachers in Enhancing Students' Spoken English by Using Video Conference in English Online Based Course
}

\author{
Adef Silfia ${ }^{1 *}$ and Hamzah ${ }^{2}$ \\ ${ }^{1}$ Universitas Negeri Padang, Padang, Indonesia, \\ ${ }^{2}$ Universitas Negeri Padang, Padang, Indonesia \\ *Corresponding author.Email: adefsilvia05@gmail.com
}

\begin{abstract}
Video conference is one of the latest media tools used in English language teaching. Online education has adopted this media to conduct teaching virtually. This requires the educationist to get used to this technology which is constantly developing. Nonetheless, it is seen that the barriers to use the online classroom activity still occur in different ways. This study aims to explore the strategies used by online instructors to enhance students' spoken English based on the existing levels, namely beginner, intermediate, and advanced level. Focusing on the possible strategies used by the teachers, the researcher used a descriptive qualitative method and the data were collected by interviewing teachers and video recording teachers. The subjects of this study were the teachers who were teaching online at the current period (September - November 2020). This research finds that teachers in beginner level tend to use role play, drilling and games. Picture describing strategy in the intermediate level is used the most, and group discussion is the strategy most observed at the advance level. In conclusion, this research shows that using the strategies in online classroom could affect students creativity in improvising their spoken English.
\end{abstract}

Keywords:Teacher's strategies, spoken English, video conference, online-based course

\section{INTRODUCTION}

Over the decades, English has become one of the most important languages to be used in many occupations of people around the world. The dependence of having skills in English language encourages people to enhance their skills either in speaking, listening, writing or reading by using several alternative efforts. English courses can be classified into two types; offline course and online course. Offline course is also known by face-to-face learning where the teacher and the student are meeting physically in a classroom. The development of technology enables the educators to conduct the teaching through online based platforms. Therefore, for the sake of innovation in teaching and learning, the teachers are demanded to be able to operate the computer and have competence in technology use in their teaching. Besides, online based course also has the superiority in blending the media into the technology where the material is also able to be displayed. The ease of the different types of technology and media which is integrated into the material is one of the advantages of an online course [1]. Therefore, online learning activity can be a medium for the instructors and learners to conduct the class from the distance.
Related to the two types of courses in teaching English especially in spoken language, it is important to recognize the way students are placed, based on their proficiency which probably obtained by conducting the placement test. The most well-known standardization of assessing language proficiency; CEFR (Common European Framework of Reference for Language) classifies language user's proficiency between beginner, intermediate, and advanced level [2]. Thus, one class in a course should be contained by the same level of students to aid the teacher in designing the appropriate syllabus, material, lesson plans, activities, and even the strategies used by the teacher to be used in the classroom.

Melendez, R, Zavala and Mendez [3] found out that fillers, circumlocution, asking for clarification, expressing not understanding has increased students' speaking skill, and the students obtained more confidence on their verbal communication. After that, Warnidah [4] specified the finding strategies on the twelve level of high school students. She claimed that the use of debate improved students' speaking performance simultaneously with their creative thinking. Gallery Walk Technique, Experience-based learning strategies, and Comprehension check strategies increased students speaking ability [5, 6, 7]. Another type of strategy, Zohairy [8] found that pair 
work strategies illustrated the different perception between Saudi students and the teacher. On the advanced level, Ma and Oxford [9] suggested that personal diary could positively affect students listening and speaking ability. Dincer [10] found out that the advanced learners such as monitoring themselves with the mirror techniques, imitating, and self-talk, mostly use self-practice strategies. The learner needs to pay attention more to the fluency and accuracy.

Conversely, in online courses, the previous studies mostly paid attention to the efficiency of using online platforms. Beltran [11] mentioned that the MOOC (Massive Online Open Courses) will make the beginners be able to learn the meanings of words in English. Next, the related study, which researched about the efficiency of platform, also appeared. Bran and Grooseck [12] mentioned that in the university level, Small Private Online Course (SPOC) showed that some features in the platform encouraged the students to do more activities, which involved their speaking. Moreover, Kuama and Intharaksa [13] analyzed the suitable activity to conduct online learning to English language students. It was assumed that metacognitive strategies and affection within online meeting affect the students' result on their speaking in online English learning. Rodrigues and Vthamani [14] investigated English Proficiency in Conversation (EPiC) in online learning for intermediated levels that can boost students speaking grades and their vocabulary.

Designing the strategies in a course, either in offline and online course seems to be necessary to increase the quality of teaching. Experts on the teaching of speaking have demonstrated the strategies that can be used in teaching activities. Thonbury [15] proposed the strategies that can be used in the speaking activity: 1) drilling and chants; 2) writing task; 3) reading aloud; 4) assisted performance and scaffolding; 5) dialogues; 6) communicative tasks; and 7) task repetition. In addition, Maulidar, Gani and Samad [16] also mentioned the other possible strategies to enhance students' speaking: 1) role play; 2) drilling; 3) games; 4) picture describing; 5) discussion group. These two theories are used on this research to study which strategies the tutor in each level prefer to apply in their online class.

However, most research on teaching strategies as reviewed above only concentrated their investigation on the strategies in offline course but vaguely discussed about the strategies used in online based course based on CEFR levels. Moreover, within this new normal era, especially in covid-19 pandemic, conducting video conference is massively done by online course. It is true that some studies have been focused on online strategies, but it still requires further study to see how the students are really thought in the classroom and the features that can be used during online meeting. In addition, spoken English became the essential integrated skills where speaking and listening skills have the important role in communication. With this online classroom, the researcher intends to look for the possible strategies that teacher applied in online course. The research can be done by analyzing the teacher's strategies by using descriptive qualitative research. Thus the appropriate strategies used by the teachers in enhancing students' spoken English by using video conference in online based course based on each level beginner, intermediate, and advanced can be studied and distinguished in the same way as done in offline based course.

\section{METHODS}

This research is a descriptive qualitative research. Gay, Mills, and Airasian [17] emphasized that descriptive qualitative research aims to understand what is happening and why. Data source in this research focused on the teacher's strategies in enhancing students' spoken English by using video conference in online based course. The subject of this study and the teachers are part of an online based course which is named English Madany. To collect the data, the researcher interviewed the teachers in the different level and recorded the meetings to observe the activities in the classroom. After collecting the data, the researcher analyzed it and classified the strategies used by the teachers in the different levels.

\section{RESULT AND DISCUSSION}

The video recordings and interviews have been identified and analyzed by the researcher. The teachers were asked about their teaching mechanisms and the activities used which represented their different strategies. Some points seemed to be essential in order to deliver the materials and design the teaching activity simultaneously. In the interview, the indicators have been classified based on the criteria as follows:

\section{Features used in Zoom us application}

Generally, some features that can be used in online meeting are the screen share, breakout room, white board share, audio share etc. Mostly, all of the levels regularly use the screen share to show the lesson to all students so students can follow the text and practice together with other students. This screen share also benefits the teacher in correcting the students' homework, sharing the power point, and pictures to describe by the students. Besides screen share, the white board share can also be used by the teacher to write down the materials. However, the teachers tend to use screen share to explain the material, either in beginner, intermediate, or advance level. The materials are based on the syllabus provided by the company 
where it is categorized based on the students' level. Each level is held eight meetings in a month yet the materials are given five times in a week. Thus, the meeting by using video conference is held twice a week. Another feature, breakout room is continuously used by the teacher in intermediate level. However, for the teachers in beginner and advanced level, the direct communication is preferred. Besides, some lessons are provided by the audio recording as what is contained in the module to aid the students to recognize correct pronunciation in English and the example of conversation. Moreover, this section is also regarded as the listening section in order to train students' spoken skill.

\section{Managing the time for question and answer}

Questioning and answering became the important activity to be conducted in online meetings. This is done to know the students understanding about the topic delivered by the teachers. Generally, before conducting the activities, the teachers deliver the materials by using screen share within no longer than 30 minutes including the icebreaking. Question and answer are usually done while and after the teachers explain the materials. The teachers make sure that all of the students understand the material well by allowing them to ask questions. Furthermore, the students are encouraged to turn on their camera, so the teachers can control and make sure that the students is listening the teacher or other students well. The massive problem in online class that used video conference is the students are not cooperative to use the camera for some reasons. Thus, the teacher suggested that when all of the students are able to show their face, the teacher can be easily to engage with them and the interaction between teacher and students is more convenient.

\section{Strategies which are used during the teaching}

There are some strategies used by the teachers while conducting the meeting by using video conference in online based course

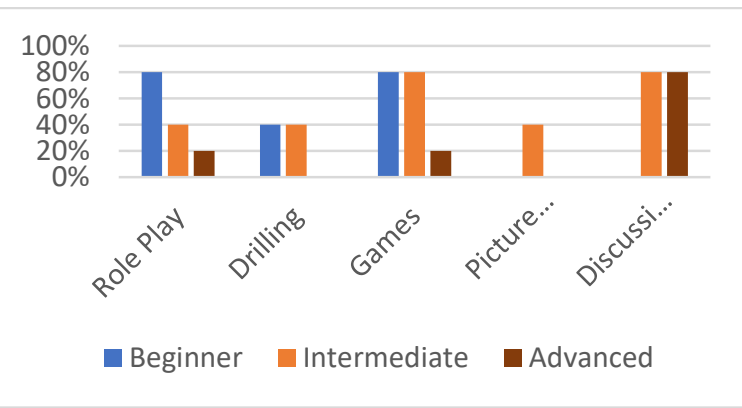

Figue 1 the Strategies Used by the Teacher in Online Based Course at beginner, intermediate and advanced level
Table 1 show that the strategies used by the teachers in online based course are various. For the beginner level, the strategies used the most in video conference are role play, drilling, and games. The beginner level teacher mentioned that these activities fit the students in making the students use the new vocabulary that they have found in the materials. Students' tasks are designed to make the students practice some simple vocabularies and expression. Some examples are also provided in the lesson materials but the students are allowed to do some more of improvisation to bring fun atmosphere to the class. To make the students prepare well, the teacher sometime gives the students time to discuss around 10 minutes in the breakout room before they perform it in front of the class.

Furthermore, in the intermediate level, the students are challenged to do more tasks and they are demanded to use more complex and spontaneous expressions. The teachers in the intermediate level claim that by using games, the students are triggered to express their idea in speaking. After that, the lesson materials also consisted of the discussion topic, so the students can be divided into group and discuss about the topic given. As well as conducted in the beginner level, the intermediate level used break out room to let the students discuss in pairs. Another strategy used in intermediate level is the picture describing. In this section, the teacher will give the picture cued, after that, the students are asked to describe that picture in simple ways.

Overall, the frequency and design of strategies used in beginner and intermediate level are almost the same; however the portion might be different. For example, role play strategy is not used as much as in beginner level when the students are already in intermediate level. In addition, picture describing strategy is given when the students are already in the intermediate level.

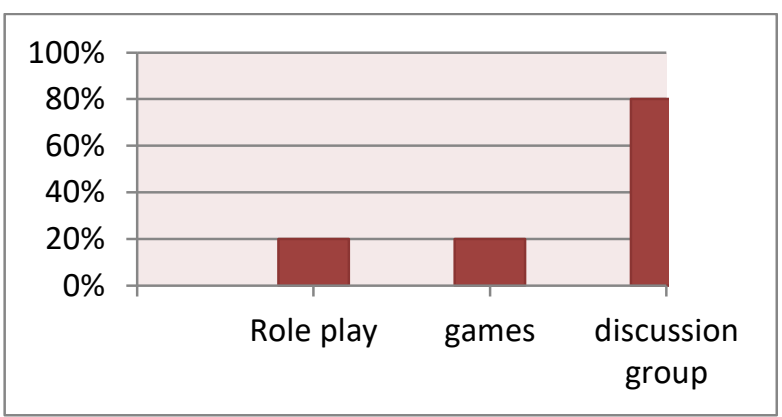

Figure 2 the Strategies Used by the Teacher at Online Based Course in advanced level

Table 2 shows that the strategies used in advanced level are more oriented towards the discussion groups. This is used to train students to show their ideas, 
critical thinking, and their opinion about random subject. Ordinarily, the students are given some topical issues inside or even outside of the country. So the students can give and obtain their general knowledge because the can share with other students. The communicative task which enables the students to give the feedback to other students is also considered in the advanced level. Even though the discussion group is used the most in this level, it can be seen that role play and games are also included with the low intensity.

\section{The alternative plan used by the teachers}

Teachers are demanded to plan more than one activity in one meeting in order to avoid the unwanted situation such as boredom, the short discussion, or even the issues of the technical problem. Here, the researcher has found that most of the teachers had an alternative plan to prevent some possible issues in online meeting. First, the teachers use the other readings to be discussed. The readings are very useful and it can be the path way to make a little discussion to train students' to think critically and to know their understanding by observing the vocabulary that they use in their speaking. Secondly, the teachers also prepare some games to motivate the student to speak by using simple expression spontaneously and improvise it. After that, the analytical questions are also prepared to train students' analysis simultaneously with their speaking. Through these alternative plans, the teachers expect that they can prevent unexpected issued which might occur in online classroom.

\section{CONCLUSION}

Based on the finding of this study, it can be seen that the strategies used by the teachers in online course are distinguished based on the level they teach. Teaching spoken English online seems to be a complex activity because the teachers need to combine the useful feature in zoom us application and the teaching strategies in the same time, which indeed it would make the difference with offline classroom. Thus, by combining the facilities in video conference application, those strategies can be done effectively to encourage the students to speak English. The numerous activities seemed to be useful in beginner and intermediate levels because the students have plenty opportunities to practice their vocabulary and expression that they learn in the materials. This indeed benefits them to memorize the words. However, the student's critical thinking in advanced level is the paramount because the students are assumed to have sufficient skill in speaking and they are brought to the comprehensive talk such as discussion group. Therefore, the strategies in advanced level are more dominated by the discussion group.

\section{REFERENCES}

[1] Weller, M. "Delivering learning on the net: the why, what \& how of online education" In Choice Reviews Online (Vol. 40, Issue 07), 2003

[2] Hulstijn, J.H. "The shaky ground beneath the CEFR: Quantitative and qualitative dimensions of language proficiency" Modern Language Journal, 91, 2007

[3] Melendez, R, Zavala \& Mendez "Teaching speaking strategies to beginners" International Scientific Forum Vol. 1, 2013

[4] Warnidah, N. "Implemantation debating technique in teaching speaking. Center of Language Innovation" Journal of Linguistics and Language Teaching Vol 2 No. 2 October 2015

[5] Namaziandost, Ehsan et, al "Pedagogical efficacy of experience-based learning (EBL) strategies for improving the speaking fluency of upperintermediate male and female irabiab EFL students." International Journal of Research in English Education (2019) 4:2

[6] Namaziandost, E et, al "The effect of gallery walk technique on pre-intermediate EFL learners' speaking skill" Language Teaching Reasearch Quarterly, 2018, Vol. 8, 1-15

[7] Namaziandost, E \& Imani. "Compensatory strategies and Iranian intermediate EFL learners' speaking fluency: focusing on self-repitition and comprehension check strategies." International journal of linguistics, literature and translation Vol. 32020

[8] Zohairy, Said. "Effective pairwork strategies to enhance saudi pre-intermediate college students' language production in speaking activities" European Scientific Journal January 2014 Vol 10

[9] $\mathrm{Ma}$ and Oxford. "A diary study focusing on listening and speaking: the evolving interaction of learning styles and learning strategies in a motivated, advanced ESL learner" ELSEVIER 2014, 101-113

[10] Dincer, A. "Proficient speakers of English as a foreign language: a focus group study" IAFOR Journal of Education. Language Learning in Education Vol. 8 Issue 1, 2020

[11] Chacon-Beltran. "Massive online open coursesand language learning: the case for a beginners' English course" Social and Behavioral Sciences 141 (2014) 242-246

[12] Bran \& Grosseck. "Speaking about SPOC: Can a small private online course (SPOC) be a viable solution for teaching English?" Scientific Bulletin of the Politehnica University of Timisoara Transactions on Modern Languages Vol. 18, No 1022019

[13] Kuama \& Intharaksa. "Is online learning suitable for all English language students?" PASAA, Vol. 
52, July-December, 2016

[14] Rodrigues, P \& Vethamani. "The impact of online learning in the development of speaking skills." Journal of interdisciplinary research in education Vol. 5, Issue 1. 2015, pp 43-67

[15] Thornbury, S. "How to teach Speaking" London: Longman, 2005

[16] Maulidar, Gani, \& Samad. "Teacher's strategies in teaching speaking for cadets" English Education Journal, 10 (1), 80-94, January 2019

[17] Gay, Mills \& Airasian "Educational Research Competencies for Analysis and Applications" USA: Pearson Education Inc, 2012 